\title{
Producing Documentary Film as A Project on Project Based Learning Approach in Improving Critical Thinking
}

\author{
Rizki Dhian Nushur \\ STKIP Bumi Persada Lhokseumawe, Aceh \\ rd.nushur@gmail.com

\section{Diyana Dewie Astutie} \\ STKIP Bumi Persada Lhokseumawe, Aceh \\ diyana_d@yahoo.com
}

\begin{abstract}
Expert says that having a critical thinking enables a person to decide about the right or wrong, so that problems can be handled responsively. Then, education is expected to facilitate students to be able to face and solve various problems agile. The learning approach taken must be able to facilitate students with teaching materials related to their lives, experiences and interests, so that they can relate them to real life. The learning approach that will be examined in this study is the PjBL Approach. This research aims to improve the critical thinking of students as the nation's next generation, so that they are able to face and solve various problems appropriately. The research was taken place in the training class which is held by Aceh Documentary Foundation in Banda Aceh. They have continuosly use this learning approch in their producing documentary film training. Data collection was carried out through observation, interviews, and FGD. Data analysis used in this research is the Miles \& Hubermen style, in which activities in the analysis included data reduction, data display, and conclusion drawing / verification. The results of this research showed that the use of PjBL approach was indeed effective in increasing students' critical thinking because they practiced the knowledge they had acquired directly. However, the results obtained by each individual are different; Even though there was an increase in the way they thought, the level of criticism that was obtained by each student was different.
\end{abstract}

Keywords: Project Based Learning, critical thinking, film documentary https://doi.org/10.24036/jess.v5i1

\section{Introduction}

Human need in thinking critically is increasecontinuesly based on the changing of times. Various problems that arise in social life and the world of work demand to be resolved quickly and precisely (Rodzalan and Saat, 2015). Here, having a critical mindset enables a person to decide the right or wrong of the event (Moore and Parker, 2009), so that problems can be handled responsively.In dealing with this problem, education must also be energized with the needs of the times. It means education is expected to facilitate students to be able to face and solve various 
problems agile (Soleimani, Rahimi, and Sadeghi, 2015). This critical thinking attitude must be accustomed and instilled since a person is in education so that it can become a culture, that is, by continuously being created in the learning process (Nushur and Astutie, 2019).The learning approach taken must also be able to facilitate students with teaching materials related to their lives, experiences, and interests, so that they can relate them to the real life (Martelli and Watson, 2016).

The more mature a student is, the richer and more complex the assessment can be given (Carless, 2015). However, this did not escape the learning process that was received. A student who is not sharpened in his thinking will be someone with a weak mindset. In addition, the lack of a critical thinking can lead to wrong reasoning and wrong decision making that ultimately has to face serious consequences (Carless, 2015).

Currently, education practitioners continue to strive to create innovative learning methods and approaches, one of them is Project Based Learning or PjBL. This approach is complex in nature which results in realistic products, activities, and presentations (Kean and Kwe, 2014). The learning processalso goes through various activities, such as examining, researching, understanding, finding alternative solutions, and applying them in the real world (Kean and Kwe, 2014). This approach is also instructional in which the tasks given look real (Mulhayatiah, 2014), that is, they have a close relationship with everyday life, so that it can provide challenges for students in solving any problems that arise in various ways (Mulhayatiah, 2014). In addition, this approach is also innovative in the learning process because it teaches various critical problem solving strategies that make it as one's current success (Bell, 2010).

During the PjBL learning process, students gain various kinds of knowledge and skills from various fields through a series of activities carried out (Tamim and Grant, 2013). They gain knowledge by questioning various things related to their natural curiosity (Bell, 2010). Each question will be studied and analyzed in depth until finally a conclusion occurs.

Aceh Documentary (ADC) foundation is an educational institution, film production and appreciation, and film development research, especially documentaries. since 2013, it has continued to strive to improve the skills of community groups in all aspects of cinema. They have produced so many documentary film since then. They also regularlyhold"Aceh Menonton" as a medium to discuss about the social issues and documentary films produced in Indonesia and abroad. It is hoped that the trainee and alumni of ADC can actively participate in this FGD activities.

In the research entitled "Producing Documentary Films as Projects on the PjBL Approach in Improving Students Critical Thinking", the formulation of the problem that will be raised is how the production of documentary films can improve students' critical thinking patterns. So that the purpose of this research is to improve students' critical thinking through this project. Documentary film itself is one of several types of film that is most suitable to be adopted as a medium or form of learning, because in its production process, it raises facts about issues in social life (Rikarno, 2015). Through this documentary film, students will carry out several stages of learning according to the $\mathrm{PjBL}$ approach, namely determining basic 
questions (essential), designing project planning, compiling schedules, monitoring project progress, testing learning processes and outcomes, and finally evaluating learning experiences (Delisle, 1997).

\section{Literature Review}

\section{Critical Thinking}

Critical thinking is an art in analyzing and evaluating a situation or event with a view in order to improve its mindset (Paul and Elder, 2006). However, this critical thinking cannot be owned by every individual easily. Humans are not just destined to decide something, but are given the mind so they can consider whether a decision is right or wrong (Soleimani et al., 2015). Critical thinking is a skill that must be practiced continuously (Nushur and Astutie, 2019). The more often someone trains it, the better the analysis given. This shows that critical thinking are not a set of thoughts that can be used at any time in any context, but require regular practice in order to be successful (Willingham, 2007).

The ability to think is certainly owned by every individual, because this is human nature. However, many people allow their thinking to be biased, distorted, partial, uninformed, and have false prejudice (Paul and Elder, 2006). This can affect the quality of life and the results to be achieved by a person, because the quality of thought, however, can affect the quality of life (Paul and Elder, 2006).

Everyone who has been nurtured and is able to think critically will formulate the problems they face clearly and precisely. They will collect and evaluate any information in order to interpret it carefully, resulting in solutions and conclusions that make sense because they go through the testing process with relevant criteria and standards (Paul and Elder, 2006). They make assumptions, think openly, recognize and judge as necessary, then make implications. In addition, they are also able to communicate well in finding solutions of complex problems.

There are several criteria of critical thinking which can be called FRISCO (Focus Reason Inference Situation Clarity Overview) (Ennis, 1985). The focus referred here is focus on questions and issues to make decisions about something that is believed. Reason here is identify and judge the reasons are acceptable or not. Conclusion here is to provide such conclusions that have been madebased on facts and assumptions. Situation here is the ability to understand situations around. Then, Clarity here is to check the clarity of language use and review the overall conclusions taken. This critical assessment of critical thinking will be used in this study.

\section{Project Based Learning}

Project Based Learning was first introduced by David Snedden to teach science in agricultural vocations in America (Beckett and Miller, 2006). Then this learning model was developed by John Dewey and Kilpatrick to emphasize the importance of learning based on experience and action (Cho, 2010). The project method proposed by Kilpatrick in 1918 emphasized the direct involvement of students in creating knowledge while solving problems they faced during the project (Brubacher, 1947). So it can be said that the emergence of the PjBL approach starts 
from a constructivist view that refers to contextual learning (Kamdi, 2007). Students who learn from text and teachers without practicing and getting direct experience during the learning process can reduce their ability to solve problems later in life, especially if they remember that life is static and constantly changing (Dewey, 1938). In other words, they will be less prepared to take advantage of the opportunities that exist today to face the life that continues to develop in the future.

The project method has been known as an alternative to learning in the field of general education literature (Cremin, 1964) (Gull, 1933), and PjBL is a learning model that involves a project (Jagantara, Adnyana, and Widiyanti, 2014). This learning model is designed to be used in complex types of problems which require investigation to understand them. In this learning model, opportunities to convey ideas, listen to other people's ideas, and reflect on their own ideas on other people's ideas can be applied well. The application process is a form of knowledge empowerment experience (Mulhayatiah, 2014). The project is carried out by students both individually and in groups, which is collaborative, innovative, unique, and focuses on problem solving and will be implemented within a certain timeframe. The resulting product will then be displayed and presented.

\section{Film Documentary}

The term documentary was first used by John Grierson in his writing in the New York Sun magazine on the February 8th, 1926 issue to criticize the film Moana: A Romance of the golden age by Robert Joseph Flaherty (Ratmanto, 2018). There he mentioned that documentary films are actual creative reports (Ayawaila, 2008). In contrast to fictional films that rely on imagination, documentary films rely on factuality and have a claim to the truth of an event that is presented or disclosed (Aufderheide, 2007).

At present, documentary and fiction films can be viewed from four different criteria, namely first, every scene in the documentary film is lifted from actual events without imaginative interpretations as found in fiction films, the background documentary film must be spontaneous, authentic and in accordance the authenticity of its condition. Second, the narrative used in documentary films must be in accordance with reality, not imaginative as in fictional films. Third, the documentary film director makes observations on a real event, then records images according to the actual events. Fourth, the story structure in documentary films refers to the content and exposure, not the plot or storyline as in fiction films (Ayawaila, 2008). So that it can be said that documentary films are a visual form of a scientific work, because they are based on a scientific attitude in the process of cultivating them, namely an attitude of curiosity; so that they make observations and formulate questions related to the issues raised, then have a critical and realistic attitude by continuing to collect strong evidence in drawing conclusions without any change events and data, then being honest and objective; that is, not biased or dominated by personal thoughts in presenting data, and being diligent in its cultivation by not stopping in carrying out activities if the cultivation has not been completed. 


\section{Documentary Films in Learning}

Documentary films are not only used to represent social issues, but can also be used to educate, raise awareness, and form certain attitudes in individuals (Irawanto and Octastefany, 2019). So that this type of documentary film is very suitable for using in the world of education. In addition, this idea is also based on government regulation number 23 of 1999 concerning the implementation of hand-over and management of story films or documentary films which basically have an important role in supporting development, especially in the fields of education, research, development of science and technology, and dissemination of information (Rikarno, 2015).

Several studies that use film as a learning medium have been done before, including research with the title " Film documenter sebagai media pembelajaran siswa" (Rikarno, 2015) and " Keefektifan film documenter sebagai media pembelajaran menulis argumentasi pada siswa kelas X SMA tiga Maret Sleman Yogyakarta" (Nurlaelah, 2014).In addition, many researches on PjBL have been conducted before. Among them; Research entitled " Pengaruh Pembelajaran Berbasis Proyek (Project Based Learning) Terhadap Hasil Belajar Biologi Ditinjau Dari Gaya Belajar Siswa SMA " was conducted by Jagantara, Adnyana, \& Widiyanti (Jagantara et al., 2014). This study aims to examine differences in $\mathrm{PjBL}$ and direct teaching learning models by reviewing student learning styles. In addition, a similar research was also conducted by Agny in the field of language education in order to improve students' written skills (Anggara, 2017).

Some of these studies show that PjBL is often carried out in various fields of science. However, it is rarely found in the social field that focus on literature and language, especially when using documentary films as a project that must be carried out in learning. Documentary films are usually taken as teaching materials or learning media. The PjBL learning approach is also very suitable to be applied in language and social issues. Therefore this research focuses on How documentery film as a project on the PjBL approach improve students' critical thinking?.

\section{Method}

This research used qualitative research methods. According to Miles \& Hubermen (Miles and Huberman, 1984), activities in analyzing qualitative data occur interactively and continuously during the research process so that no new information is found in the data, or the data becomes saturated. This reseach was done in Aceh Documentary (ADC) Foundation which is based in Banda Aceh. The trainee of documentary films production 2019 was contributing and being the participants in it.Then the sampling technique used was purposive sampling, which is taking samples with certain defined criteria, namely being active as a student, participating in the documentary film production program at the Aceh Documenter Foundation, and passing the selection of documentary film theme selection in 2019.

In obtaining research data, data collection techniques that will be used in this study consist of observation, interviews, and FGD. Observations were made from before the research was carried out; namely field observations to obtain data from the learning participants and other needs, then during the implementation of the 
activities to review the implementation and progress in learning, and finally at the presentation of the project results (documentary film) to see to what extent the success of this PjBL learning. Interviews carried out before and after the research was done to measure the level of criticality of the students' mindset who were as the learning participants. Then FGD was carried out after the learning process was done. From the results of the analysis, it will be known to what extent the learning method has been successfully applied. The data collected during the research process will be analyzed in accordance with the method of analyzing data in qualitative research. The data analysis model used in this study is Miles \& Hubermen's qualitative data analysis, which activities in the analysis include data reduction, data display, and conclusion drawing / verification. First, all data that has been collected throgh observation, interview and FGD in the research process will be sorted and decided on which data is considered important and which is not, then the data deemed unnecessary was reduced. Next, the previously sorted data will be presented in narrative form. Then finally the data results that have been presented will be summarized and verified so that the conclusions obtained are considered credible.

\section{Result and Discussion}

The research's results and discussion presented in this study described based on the results of observations, interviews, and FGDs. Observations were made during the implementation of the training program and guidance for documentary film production which was carried out by ADC. Then the interview was carried out twice, the first was when the participants were selected for the guidance program, and the second was when the documentary film was finished by the participants. Then the FGD was also held when the documentary film training and guidance program carried out by the ADC was completed.

Observations have been made since the announcement of the admission of participants for the annual ADC program was carried out. Prospective participants are asked to register and submit a documentary film proposal that they want to work on in accordance with the given theme. The theme raised was Geunulam. Geunulam is an Acehnese word which means to bear. The process of receiving training scholarships for documentary film has a series of activities, namely selection, basic training, forum meetings, in-house training, production, post-production (editing), and documentary film awarding nights.

At the selection stage, the students have to give information needed that has been provided in the application form; a synopsis of the story idea, the subject; the character to be appointed in the documentary, a description of the location, and the source of the idea. For the first stage of selection; to determine the 10 story ideas that pass and participate in the Basic Training program, the selection is made based on the writing (proposal) sent by the participants. The selection team will read, assess, and consider the potential of the story idea using visual considerations (film).

The next process is Basic training. In the Basic training stage, all participants consisting of 10 teams with story ideas that have passed the first stage selection will 
be invited to Banda Aceh for 4 days to be introduced about several things related to documentary films, namely photo stories, documentary film research, cinematography. Generally, this will provide the participants with a provision to continue their research on the story idea. They will focus their research on the scope of visual research, and empirical data that will be visualized later.

After the Basic Training, participants return to their respective areas to conduct further research which is carried out again in depth using the knowledge they have acquired in Basic Training. In addition, they also conduct research on the subject and the problems they face. Here the participants have determined the point of view about the story would be told in their later documentary films. The collected data will be presented at the Pitching Forum stage, also known as the forum meeting.

At the Pitching Forum, participants will present the data they get according to what they have learned in basic training. The important points that must be presented are the film synopsis, logline, statement film, as well as the visual potential of their film in the form of photographs. From here, five teams with strong stories will be selected to be scholarships awardee; in the form of documentary film production training for more than one month.

The next process is to attend In-House Training; which is also a part of this scholarship stage. Here they learn to manifest the story idea in a form of script or scenario; they learn to put the story together into a documentary film. In addition, they also studied cinematography in depth. Cinematography is useful for participants to choose their depiction through the camera (video), with their semiotics. Participants also learned about editing and combining images into a complete film with visual logics. Besides, the participants are also given education about film production management, where they must consider all film production costs effectively.

After In-house Training, participants will carry out a film production process in the field for 10 days. What they write in the scenario (script) will be manifested in the form of images or videos with cinematographic considerations, which they will incorporate in the editing process. This editing process will be carried out in Banda Aceh using the ADC's computer.

At the editing stage, participants will meet the rough cut process (preview for rationalizing the editing method) for 3 times; rough cut 1, 2, and 3. After that, the film will be locked, which means that the structure cannot be changed. The film will be screened in the regions by the ADC distribution team. After this series of processes, ADC held an Awards Night, by selecting the best film from among the five films produced. The jury will be selected from outside the ADC team (usually from journalists, humanists, etc.). On Award night, the judges will also provide comments for all the films that have been produced.

Data collection by interview was carried out twice, namely before the training program was implemented; at the time of selecting proposals for documentary film work, and after the documentary film production program is completed. The interviews were focused on participants who passed the selection for the documentary film training program. There are two groups selected, each of which consists of two participants. The first group raised the title "Minor" and the second 
one raised the title "Klinik Nenek" (Grandma's clinic). In this study each participant will be named P1, P2, P3, and P4.

Based on the results of interview I and interview II, it was found that the participants' critical thinking increased. In the first interview conducted before the documentary film training process was carried out, the answers given by the participants were still rather superficial, so it could be concluded that their critical thinking was still in very minimal stage. However, after participating in the documentary film-making process from start to finish, it turned out that not all participants had drastically improved their thinking, even though there were still improvements. This could be caused by several factors. One of them is because the work on this documentary film is done in groups so that one of them may be less active or one of the others is more dominant in making the film. In addition, psychological factors also have an effect, where not everyone has the same information absorption and intelligence. However, of course to get maximum results they have to routinely do exercises in making other documentary films so that their abilities are increasingly honed. Below will explain the improvement in the participants' thinking in detail.

P1 and P2: In the first interview they gave similar answers because they were in the same group and were conducting the interview stage simultaneously. They presented the idea of making Minor films with questions in accordance with what they described. In addition to the core questions as a guide, the interviewers also expanded their questions according to the explanation given by the participants, so that the extracting of information obtained from the participants could be more detailed. It can also sharpen their critical mindset by thinking more deeply about the answers given to the questions posed.

P3 and P4: Similar to P1 and P2, they also conducted the first interview simultaneously. They are required to be able to present the film that they will adopt. However, even when conducting the interview in one group, the interviewers will still ask some questions personally, even though some other questions are asked for both of them so that anyone of them can give the answers. As was also experienced by $\mathrm{P} 1$ and $\mathrm{P} 2$, the interviewers also gave personal questions according to the explanation they gave, although core questions were still thrown for both of them. Each question posed by the interviewers has the aim of obtaining information to determine the feasibility of the film they have submitted to be considered appropriate.

The Forum Group Discussion (FGD) process was carried out after all the training activities and the production of selected films had been produced. During the FGD, the participants looked enthusiastic and the discussion became more and more interesting on each opinion given. Of the four participants who took part in the FGD, two participants, namely P1 and P3, were more prominent in giving arguments. This can be influenced by the idea that the story is made into the film from them, while $\mathrm{P} 2$ and $\mathrm{P} 4$ are those who accompany or are invited to participate in the success of the production of the films they have produced.

According to $\mathrm{P} 1$, this documentary film training has really made them more sensitive to what is happening around them. The 10 days training made them more critical because they were trained to question everything in detail and 
fundamentally. Several times they felt overwhelmed, but each process became very interesting, sometimes they had to give two presentations a day. Every argument they give must have a basic reason. The answer to the "why" and "how" of a statement seems to be obligatory for them.

Just like P1, P2 also said that they were overwhelmed by the series of activities they had to go through during the training process so that they felt like giving up, but because they work in a team, they can support each other when one of them falters. The training activities carried out by Aceh Documentary really drained their energy and minds, but all that fatigue certainly produced sweet results, because in the end they became accustomed to thinking more deeply and fundamentally when dealing with problems encountered in the field. Even today, when the filming is finished, the way of thinking as applied to the training is still carried over in their daily lives.

P3 also agreed with the opinions given by her friends. According to her, the training activity was very natural to make them tired because every science of film; from planning of filming to the final editing process, they learned in ten days. She said, the ten days was a very short time to study the whole science of the documentary film. Their minds and bodies were suddenly forced into intense activities that they had never done before. This of course shocked their bodies. P3 added that their bodies and minds are used to being too relaxed and inattentive to become lazy in moving and thinking. Therefore, when they are faced with a situation that requires them to be physically active and think, they will feel exhausted and overwhelmed. The tired feeling of thinking critically will disappear over time if we continue to apply this critical thinking pattern in our daily life, so that critical thinking is no longer a requirement but a habit. She is very grateful to Aceh Documentary for the learning opportunity provided through this documentary film training scholarship program.

P4 also agrees with her other colleagues, it's just that according to her, the basic training process on the theory of film cultivation for ten days can be increased to 15 days or more. The learning process that is rushed and under the pressure of deadlines is certainly less effective than the learning atmosphere which is more relaxed. Especially for those who are beginners. However, of course the learning process has been able to shape the alumni to be more critical in thinking. The habits of questioning everything fundamentally and in detail carried over in their daily lives. She said, this ability will disappear if it is not continuously sharpened.

From the results of the FGD that was carried out, it can be seen that the application of the critical thinking they have learned during the documentary film production training held by Aceh Documentary has become a habit in their daily lives, so this habit makes them more critic in figure out the problems they faced. Their critical thinking will continue to improve if practice after practice continues. The discussion process during the FGD became fun and in-depth because the opinions they gave sounded simple but heavy. They also sounded more courageous in expressing their opinions. 
However, the results of this learning approach can be said to be quite satisfying and as expected. This can be seen from the assessment criteria of critical thinking by Ennis (1985), namely FRISCO;

Focus: here the participants are successfully trained to get used to focus on making questions and questioning issues related to the objects they are studying in making documentary film. This can be seen through observation section while collecting the data of this research.

Reason: the training participants were successful in identifying and assessing a reason that they concluded was acceptable or not, in other words, the conclusions they made had appropriate reasons.

Inference: they succeed in providing or drawing conclusions not only based on teir assumptions, but also based on the facts they got during their research in the documentary film they were working on.

Situation: The training participants also succeeded in analyzing and understanding the situation in their documentary film production, so that the results achieved were satisfactory. The success of analyzing this situation can also be seen when they answeredthe questions during interviews and also in conducting discussions during FGD.

Clarity: here, the clarity of the use of language in the conclusions they draw can be seen from the documentary film they were working on. They have reviewed the entire documentary film project before finally summarizing it in a neat documentary work.

\section{Conclusion}

According to research, it can be concluded that the production of documentary films can increase the critical thinking of students who are participants in the documentary film production training which is held annually. The participants who were selected as recipients of the training for film making took part in the various stages of the test held by the ADC, where at each stage of the test, the participants had also indirectly applied critical thinking training using the PjBL learning method, namely by determining basic questions ( essential), designing project planning, compiling schedules, monitoring project progress, testing learning processes and outcomes, and finally evaluating learning experiences.

In determining the basic questions (essential), the participants have applied them since the beginning they filled out the registration form to get the scholarship for the film. On the registration form, there are some basic questions that they have to explain, it's just that at that time they were still following the stimulation of questions from the ADC, and had not yet reflexively questioned the conditions they raised.

For the design phase of the project questions, the participants did it in basic training activities, where before designing the project they were also taught about the basics of making the documentary film. At the end of the activity, the 
participants were asked to compile questions, plan, and schedule for the documentary film that they will work on.

The project monitoring progress is carried out while the documentary film is being produced. This activity is supervised by the committee who are alumni and administrators of the ADC (Aceh Documentary). The activity supervisors will continue to accompany each group of participants during film production; including during film editing, so that they can continue to provide input for maximum results.

Testing process and learning outcomes is carried out when the participants are ready to present their work. The film that has been worked on will be screened and judged by the judges, and the best film will be given an award. Each participant will be given input as a learning evaluation, however, they will also get appreciation for the results of their hard work.

After going with the various series of activities, it can be seen through interviews and FGDs, then analyze it through critical thinking assessment by Ennis named FRISCO that show their critical thinking has improved quite significantly, even though each individual gets different results. They seem to be able to focus on formulating questions related to the issues they raise in a discussion or documentary film project, and conclude it well based on facts and assumptions. presentation of conclusions can also be done well.

Although they get a sattisfactory increase in critical thinking, however the level of this critical thinking is different. It is also seen from the intelligence abilities possessed by each individual, as well as their different backgrounds. However, the results of this learning method can be said to be quite satisfying and as expected. Thisis what supports this article which is worth reading and understanding, so that the learning process of students is enjoyable and can be more interesting with satisfying results. The learning process must also be provided by following the times.

\section{Acknowledgement}

I would like to thank the Ministry of Education and Culture, LLDIKTI K13, Aceh Documentary Foundation, and STKIP Bumi Persada Lhokseumawe for helping me in carrying out this research so that it can be completed properly.

\section{REFERENCES}

Anggara, Syamfa Agny. 2017. "Penerapan Model Project Based Learning Arabi : Journal of Arabic Studies." Arabi : Journal of Arabic Studies 2(2):186-96.

Aufderheide, Patricia. 2007. Documentary Film: A Very Short Intoduction. Oxford University Press, USA.

Ayawaila, Gerzon R. 2008. Dokumenter : Dari Ide Sampai Produksi. edited by V. S. Wardhana. Jakarta.

Beckett, Gulbahar H., and Paul Chamness Miller. 2006. Project-Based Second and Foreign Language Education: Past, Present, Amd Future. Greenwich: CT information age publishing.

Bell, Stephanie. 2010. "Project-Based Learning for the 21st Century: Skills for the 
Future." The Clearing House: A Journal of Educational Strategies, Issues and Ideas 83(2):39-43. doi: 10.1080/00098650903505415.

Brubacher, John Seiler. 1947. The History of the Problem of Education. New York: McGraw - Hill.

Carless, David. 2015. Excellence in University Assessment.

Cho, So-Eun. 2010. "PROJECT-BASED LEARNING IN A FOREIGN LANGUAGE IMMERSION CAMP.” The Pennsylvania State University.

Cremin, Lawrence. 1964. The Transformation of the School: Progressivism in American Education 1896 - 1957. New York: Vintage book.

Delisle, Robert. 1997. Used Problem Based Learning in the Classroom. USA: Association for supervision and curriculum development.

Dewey, john. 1938. Experience and Education. New York: Simon \& Schuster.

Ennis, Robert H. 1985. "A Logical Basis for Measuring Critical Thinking Skill." Education Leadership 43(2):44-48.

Gull, H. 1933. Project in the Education of Young Children. London: McDougall.

Irawanto, B., and T. Octastefany. 2019. "Film Dokumenter Sebagai Katalis Perubahan Sosial Studi Kasus Ambon, Aceh, Dan Bali." Jurnal Kawistara 1(9):107 - 119.

Jagantara, I. Wirasana Made, Putu Budi Adnyana, and Ni Putu Widiyanti. 2014. "Pengaruh Model Pembelajaran Berbasis Proyek (Project Based Learning) Terhadap Hasil Belajar Biologi Ditinjau Dari Gaya Belajar Siswa SMA.” EJournal Program Pascasarjana Universitas Pendidikan Ganesha Program Studi IPA 4(1):1-13.

Kamdi, W. 2007. "Pembelajaran Berbasis Proyek: Model Potensial Untuk Peningkatan Mutu Pembelajaran.” Http://Lubisgrafura.Wordpress.Com.

Kean, Ang Chooi, and Ngu Moi Kwe. 2014. "Meaningful Learning in the Teaching of Culture: The Project Based Learning Approach.” Journal of Education and Training Studies 2(2):189-97. doi: 10.11114/jets.v2i2.270.

Martelli, Cynthia Dawn, and Patricia Watson. 2016. "Project-Based Learning: Investigating Resilience as the Connection between History, Community, and Self." Voices from the Middle 23(3):10-16.

Miles, M. B., and A. M. Huberman. 1984. Qualitative Data Analysis. London: Sage.

Moore, Brooke Noel, and Richard Parker. 2009. Critical Thinking Highlights of the Ninth Edition.

Mulhayatiah, Diah. 2014. "Penerapan Model Pembelajaran Berbasis Proyek Untuk Meningkatkan Kemampuan Berpikir Kreatif Mahasiswa." Edusains 6(1):18-22. doi: 10.15408/es.v6i1.1096.

Nurlaelah. 2014. "Keefektifan Filmdokumenter Sebagai Media Pembelajaran Menulis Argumentasi Pada Siswa Kelas X SMA Tiga Maret Sleman Yogyakarta." Universitas Seni Yogyakarya.

Nushur, Rizki Dhian, and Diyana Dewie Astutie. 2019. "The Effectiveness of Using Hikayat Prang Sabi in PjBL Approach to Improve Students' Critical Thinking." 6(2):285-96.

Paul, Richard, and Linda Elder. 2006. "The 'Aha!' Approach or Critical Thinking and Understanding Concepts.” Pp. 1-22 in Foundation for Critical Thinking. 
Ratmanto, A. 2018. "Beyond the Historiography: Film Dokumenter Sejarah Sebagai Alternatif Historiogrfi Di Indonesia." Sasdaya Gadjah Mada Journal of Humanities 2(2):405 - 414.

Rikarno, R. 2015. "Film Documenter Sebagai Sumber Belajar Siswa." Ekspresi Seni; Jurnal Ilmu Pengetahuan Dan Karya Seni. 1(17):129 - 149.

Rodzalan, Shazaitul Azreen, and Maisarah Mohamed Saat. 2015. "The Perception of Critical Thinking and Problem Solving Skill among Malaysian Undergraduate Students." Procedia - Social and Behavioral Sciences 172(2012):725-32. doi: 10.1016/j.sbspro.2015.01.425.

Soleimani, Hassan, Zahra Rahimi, and Hossein Sadeghi. 2015. "Project-Based Learning and Its Positive Effects on Iranian Intermadiate EFL Learners Reading Ability and Vocabulary Achaivement." International Journal of English Language and Literature Studies 4(1):1-9. doi: 10.18488/journal.23/2015.4.1/23.1.1.9.

Tamim, Suha R., and Michael M. Grant. 2013. "Definitions and Uses: Case Study of Teachers Implementing Project-Based Learning." Interdisciplinary Journal of Problem-Based Learning 7(2):5-16. doi: 10.7771/15415015.1323.

Willingham, Daniel T. 2007. "Critical Thinking: Why Is It So Hard to Teach?" American Educator 109(4):21-32. doi: 10.3200/AEPR.109.4.21-32. 